\title{
Incorporation of Residue into the Soil in Combine Harvested Paddy Field by Machineries Combination
}

\author{
Suryakant Sonwani*, M. Quasim, Ajay Verma and Pushpraj Diwan \\ Department of FMPE, SVCAET \& RS, IGKV, Raipur (C.G.), India \\ *Corresponding author
}

\begin{tabular}{|l|}
\hline Ke y w o r d s \\
Machinery \\
combination, Straw \\
length reduction, \\
Pulverization index, \\
Mixing index
\end{tabular}

A B S T R A C T
Presently keeping up the nature of soil is significant point for sustainable agriculture. We have numerous machineries and equipment to mix the residue, stubble of paddy and wheat in soil. They are mulcher, happy seeder and straw chopper which are presently accessible and used to decrease the length of stubble and help for mixing them in combine harvested paddy field. At some time we are not interested to contribute cash and buy for that kind of machinery for single tasks because of its high cost but it is very important to avoid the burning of residue and improve the organism matter in the field. In this research two different combination of machinery was used for soil residue incorporation. Test was conducted in combine harvested rice field of Faculty of Agricultural Engineering, Indira Gandhi Krishi Vishwavidyalaya, Raipur (C.G) by using a first machinery combination i.e. 1 pass of mulcher, 1 pass of disc plough and 1 pass of rotavator and second machinery combination i.e. 1 pass of straw chopper, 1 pass of disc plough and 1 pass of rotavator as treatment $T_{1}$ and $T_{2}$. Energy requirement was observed $3076.41 \mathrm{MJ} / \mathrm{ha}$, $3155.91 \mathrm{MJ} / \mathrm{ha}$ and cost of operation was observed ₹ 5308.22/ha and ₹ 5829.87/ha.

\section{Introduction}

Rice (Oryza sativa L.) is the most important crop of India and it occupies 23.3 per cent of gross cropped area of the country. Production and productivity of rice in India at 2017-18 was around 111.01 MT and $2585 \mathrm{~kg} / \mathrm{ha}$ respectively under the area of $42.95 \mathrm{M}$ ha
(Anonymous, 2018). Rice contributes 43 per cent of total food grain production and 46 per cent of total cereal production.

In general, farmers operate stubble shaver on paddy straw after harvesting the crop by combine harvester and then burn it. In this process about 12.6 MT of paddy straw is burnt 
in Punjab every year. It is estimated that paddy straw worth crores of rupees is burnt in the field and 38.0 lakh tons of organic carbon, 59.0 thousand tons of nitrogen, 2.0 thousand tons of phosphorus and 34.0 thousand tons of potash is lost every year in burning of paddy straw (Verma et al., 2016).

Management of paddy residues left in the combine harvested fields is a major problem in rice wheat crop rotation in India (Thakur, 2007).

Emission of smoke which if added to gases present in the air like methane, nitrogen oxide and ammonia can cause severe atmospheric pollution (Kumar et al., 2015).

The burning of residue is not only source of atmospheric pollution but also leads to loss of rich organic matter (Thakur, 2007). Straw management and crop rotation alternative to burning straw by using machinery, straw height reduction helps in decomposition of straw (Cook et al., 2000).

Erosion can be greatly reduced by maintaining a crop residue cover on the soil surface of at least 30 percent after all tillage and planting operations. Conservation tillage is one of the most effective means of cropland erosion control (Kenneth et al., 2005).

Stubble length reduced by straw chopper and also found that time for decomposition of straw with straw lengths such as $0.5 \mathrm{~cm}$, $1.0 \mathrm{~cm}, 2.0 \mathrm{~cm}$ and $5 \mathrm{~cm}$ were 24 days, 30 days, 47 days and 50 days respectively (Midwood et al., 2012).

The main parameters that affect the performance of the stubble harvester cum chopper were forward speed of the machine, chopper speed, moisture content of the stubbles, height of stubbles, plant density (Thakur, 2007).

\section{Materials and Methods}

\section{Experimental site}

Field experiment was carried out during kharif season of 2017-18. Test was conducted in combine harvested rice field of Indira Gandhi Krishi Vishwavidyalaya, Raipur (C.G). The soil of experimental site is represented as a silty clay soil mixed with sand. It is locally called 'Dorsa'.

\section{Design of experiment}

Straw management after cutting straw it was require to mix the straw in soil for proper incorporation, therefore all three operations were taken as combination i.e. cutting of straw, ploughing operation and mixing operation. So different types of implements were required for tillage and mixing operation, that implements were mulcher $\left(\mathrm{M}_{1}\right)$, disc plough $\left(\mathrm{M}_{2}\right)$, rotavator $\left(\mathrm{M}_{3}\right)$, straw chopper $\left(\mathrm{M}_{4}\right)$. Different combinations of implement are given below.

$\mathrm{T}_{1}=1 \times$ mulcher $+1 \times$ disc plough $+1 \times$ rotavator

$\mathrm{T}_{2}=1 \times$ straw chopper $+1 \times$ disc plough $+1 \times$ rotavator

Machine parameters are theoretical field capacity (ha/h), actual field capacity (ha/h), field efficiency (\%), fuel consumption ( $1 / \mathrm{ha}$ ) and energy requirement (MJ/ha). Physical properties of soil are, moisture content (db \%), bulk density (g/cc), cone Index, pulverization index and mixing Index. Physical properties of straw are moisture content ( $\mathrm{db} \%)$, straw length $(\mathrm{cm})$, weight $(\mathrm{g})$, straw population, straw uprooted efficiency (\%). Each replication for every treatment was carried out in a separate plot. The result for each dependent parameter soil (pulverization index, mixing index, reduction in bulk density), 
machine parameters and straw parameters with replications were analyzed on experimental field.

\section{Soil parameters}

\section{Moisture content of soil}

The soil moisture analysis was done by oven drying method. Randomly soil samples were collected from selected field and weight of the wet soil sample was measured by weighing balance.

The soil sample was put in hotair oven at $105^{\circ} \mathrm{C}$ for 24 hours and then the weight of dry sample was measured. Moisture content was measured by using following relation:

Moisture content $(\%)=\frac{w_{1}-w_{2}}{w_{1}}$

Where,

$\mathrm{w}_{1}=$ initial weight of soil sample, $\mathrm{g}$

$\mathrm{w}_{2}=$ dry weight of soil sample, $\mathrm{g}$

\section{Bulk density of soil}

Bulk density of soil is the ratio of mass and volume of soil. The bulk density was determined after the operation using core cutter and hammer. The diameter and length of the core cutter was $10 \mathrm{~cm}$ and $17.5 \mathrm{~cm}$ respectively. Soil samples were collected from each experimental plot and weighted.

The samples for drying were placed in an oven at $105^{\circ} \mathrm{C}$ for 24 hours. The dried samples reweighted in an electrical balance meter having maximum capacity to weight $5 \mathrm{~kg}$ and the difference was recorded. Bulk density was calculated by using following formula:

Bulk density $=\frac{\text { mass of soil sample }}{\text { volume of core cutter }}$
$\rho_{b}=\frac{M}{\pi D^{2} L}$

Where,

$\mathrm{D}=$ bulk density, $\mathrm{g} / \mathrm{cm}^{3}$

$\mathrm{M}=$ mass contained in soil sample of oven dry soil, g;

$\mathrm{V}=$ volume of cylinder sampler, $\mathrm{cm}^{3}$

$\mathrm{D}=$ diameter of cylinder sampler, $\mathrm{cm}$; and

$\mathrm{L}=$ height of cylinder sampler, $\mathrm{cm}$.

\section{Organic carbon}

Organic carbon was determined by Walkley and Black's rapid titration method (Walkey and Black, 1934). The procedure of determination of organic carbon content is given below:

$\mathrm{C}$ in soil $(\%)=[(\mathrm{B}-\mathrm{T}) \times \mathrm{S} \times 0.003 \times 1.3 \times$ $100] \div \mathrm{W}$

Where,

$\mathrm{B}=$ amount of $\mathrm{FeSO}_{4}$ required in blank titration.

$\mathrm{T}=$ amount of $\mathrm{FeSO}_{4}$ required in soil titration.

$\mathrm{S}=$ strength of $\mathrm{FeSO}_{4}$ (from blank titration).

$\mathrm{W}=$ weight of the soil.

Organic matter in soil $(\%)=\%$ organic $\mathrm{C} \times$ 1.724

\section{Straw parameters}

\section{Moisture content of straw}

The straw moisture analysis was done by oven drying method. Randomly straw samples were 
collected by selected field. The weight of the straw samples was measured by weighing balance.

The straw sample was put in hot air oven at $70^{\circ} \mathrm{C}$ for 4 days and then the weight of dry sample was measured. Moisture content of straw was measured by using following relation:

Moisture content $(\%)=\frac{w_{1}-w_{2}}{w_{1}}$

Where,

$\mathrm{w}_{1}=$ Initial weight of soil sample, $\mathrm{g}$

$\mathrm{w}_{2}=$ Dry weight of soil sample, $\mathrm{g}$

\section{Straw length}

The length of straw was taken before the operation of implements and after the operation of implements in combine harvested rice crop field. The length of twenty straws was taken randomly from each plot and average was taken. The length of straw was measured with the help of measuring tape.

\section{Weight of straw}

Straw taken randomly from each plot by using $1 \mathrm{~m}^{2}$ area frame and weight was measured by using weight balance the average was taken as weight of straw.

\section{Straw population}

Initial straw population of combine harvested rice crop was calculated using a square frame of area $1 \times 1$ meter placed randomly in the experimental field where the operation was performed. Five observations were taken from each plot and then average value of straw population was calculated in per meter square area.

\section{Fuel consumption}

In weeder petrol start, kerosene operated engine was used. The fuel consumption measured in terms of liter per hour by additional measuring cylinder. The following formula was used for measuring the fuel consumption (FC).

$\mathrm{FC}=\frac{\text { amount of Fuel required for operatoin (lit) }}{\text { time of operation (h) }}$

\section{Theoretical field capacity}

Theoretical field capacity was determined by speed of the machine and effective width of the implement. The formula used is given below

$\mathrm{TFC}=\frac{\mathrm{s} \times \mathrm{W}}{10}$

Where,

T.F.C. $=$ theoretical field capacity, ha/h

$\mathrm{W}=$ effective width of weeder, $\mathrm{m}$

$\mathrm{S}=$ speed of operation, $\mathrm{km} / \mathrm{h}$

\section{Effective field capacity}

The actual covered area during operation was called effective field capacity. In this term we consider the useful time and time loss for turning the machine.

$\mathrm{EFC}=\frac{A}{\mathrm{~T}_{\mathrm{p}}+\mathrm{T}_{1}}$

Where,

E.F.C. = effective field capacity, ha/h

$\mathrm{A}=$ area, ha

$\mathrm{T}_{\mathrm{p}}=$ productive time, $\mathrm{h}$ 
$\mathrm{T}_{1}=$ nonproductive time, $\mathrm{h}$

\section{Field efficiency}

Field efficiency is the ratio of effective field capacity to theoretical field capacity. The following formula was used for determine field efficiency.

$\mathrm{FE}=\frac{E F C}{T F C} \times 100$

Where,

$\mathrm{FE}=$ Field efficiency, $\%$

E.F.C. = effective field capacity, ha/h

T.F.C. $=$ theoretical field capacity, ha/h

\section{Energy analysis}

Energy was required to operate the machinery in field there was mainly three type of energy used i.e. human energy, chemical energy (Fuel energy) and machinery energy. The energy of the operation is calculated by following the research article (Singh et al., 1992).

\section{Cost analysis}

Cost of operation performed for all treatments was worked out on the basis of the prevailing input. The cost of operation of is divided into two heads known as fixed cost and operation cost, where fixed cost is independent of operational use while variable cost varies proportionally with the amount of use (Kamboj et al., 2012).

\section{Results and Discussion}

\section{Soil parameters}

Bulk density of field observed before and after operating the combination of different implement as treatment $T_{1}$ and $T_{2}$ i.e. shown in Table 1. The maximum reduction in bulk density was observed in $\mathrm{T}_{2}$ that was $27.01 \%$ and for $\mathrm{T}_{1} 25.58 \%$. Carbon content improvement was observed maximum in $\mathrm{T}_{1}$ that was $24.49 \%$ and $21.13 \%$ for $\mathrm{T}_{2}$.

\section{Machine parameters}

Operational speed, fuel consumption field capacity and field efficiency of different implement is given in Table 2.

\section{Straw parameter}

Average straw population was found 302.9 per $\mathrm{m}^{2}$ and weight of straw was found $604.08 \mathrm{~g}$ per meter square. Moisture content was observed before perform different combination of implement for straw management given in Table 3. Straw length reduction was found more in $T_{1}$ than $T_{2}$ given in Table 3. The maximum reduction in straw length in $\mathrm{T}_{1}$ was observed $82.01 \%$ and $81.56 \%$ for $\mathrm{T}_{2}$.

\section{Energy and economical analysis}

Energy requirement by different implements of different treatment are shown in Fig. 7. Minimum energy requirement observed in treatment $\mathrm{T}_{1}$ that was $2.52 \%$ less than the $\mathrm{T}_{2}$. The calculated energy requirement of different treatment is show in Table 4. Cost of operation of different treatments is shown in Fig. 8. Minimum cost of operation calculated in treatment $T_{1}$ that was $8.94 \%$ less than the $\mathrm{T}_{2}$. The calculated cost of operation of different treatment is represented in Table 5.

The observed data reveled that straw length reduction was helping more for straw incorporation in soil because in $\mathrm{T}_{1}$ two pass of harrow reduce the size of straw more than the machinery used in $T_{2}$ that was help to reduce the bulk density and also increase the carbon content by better incorporation of soil. Energy and cost of the $\mathrm{T}_{1}$ was found $2.52 \%$ and $8.94 \%$ less than the $\mathrm{T}_{2}$ respectively. 
Table.1 Moisture content, bulk density and carbon content of soil during experiment

\begin{tabular}{|c|c|c|c|c|c|}
\hline Sample & $\begin{array}{c}\text { Moisture content, } \\
\text { \% }\end{array}$ & \multicolumn{2}{|c|}{ Bulk density, g/cc } & \multicolumn{2}{|c|}{ Carbon content, \% } \\
\cline { 3 - 6 } & & $\begin{array}{c}\text { Before } \\
\text { operation }\end{array}$ & $\begin{array}{c}\text { After } \\
\text { Operation }\end{array}$ & $\begin{array}{c}\text { Before } \\
\text { operation }\end{array}$ & $\begin{array}{c}\text { After } \\
\text { Operation }\end{array}$ \\
\hline $\mathbf{T}_{\mathbf{1}}$ & 15.34 & 1.74 & 1.27 & 0.57 & 0.72 \\
\hline $\mathbf{T}_{\mathbf{2}}$ & 16.49 & 1.72 & 1.28 & 0.56 & 0.68 \\
\hline
\end{tabular}

Table.2 Fuel consumption, speed, field capacity and field efficiency of different implements

\begin{tabular}{|c|c|c|c|c|c|}
\hline Machinery & $\begin{array}{c}\text { Fuel } \\
\text { consumptio } \\
\mathbf{n , ~} \mathbf{l} / \mathbf{h}\end{array}$ & $\begin{array}{c}\text { Average } \\
\text { speed, } \mathbf{~ k m} / \mathbf{h}\end{array}$ & TFC, ha/h & EFC, ha/h & $\begin{array}{c}\text { Field } \\
\text { efficiency, } \\
\text { \% }\end{array}$ \\
\hline Mulcher $\left(\mathbf{M}_{\mathbf{1}}\right)$ & 5.98 & 3.54 & 0.56 & 0.49 & 87.50 \\
\hline Disc plough $\left(\mathbf{M}_{\mathbf{2}}\right)$ & 7.80 & 3.06 & 0.45 & 0.39 & 86.22 \\
\hline Rotavator $\left(\mathbf{M}_{\mathbf{3}}\right)$ & 8.38 & 3.10 & 0.46 & 0.40 & 87.39 \\
\hline $\begin{array}{c}\text { Straw chopper } \\
\left(\mathbf{M}_{\mathbf{4}}\right)\end{array}$ & 6.51 & 3.03 & 0.56 & 0.48 & 85.71 \\
\hline
\end{tabular}

Table.3 Average moisture content and straw length during experiment

\begin{tabular}{|c|c|c|c|}
\hline \multirow{2}{*}{ Treatment } & Moisture content, $\%$ & \multicolumn{2}{|c|}{ Straw length, cm } \\
\cline { 3 - 4 } & & Before operation & After operation \\
\hline $\mathbf{T}_{\mathbf{1}}$ & 15.55 & 42.47 & 7.64 \\
\hline $\mathbf{T}_{\mathbf{2}}$ & 15.86 & 42.67 & 7.86 \\
\hline
\end{tabular}

Table.4 Energy requirement of the different treatments

\begin{tabular}{|c|c|c|}
\hline Treatments & Combination & Energy, MJ/ha \\
\hline $\mathbf{T}_{\mathbf{1}}$ & $1 \times \mathrm{M}_{1}+1 \times \mathrm{M}_{2}+1 \times \mathrm{M}_{3}$ & 3076.41 \\
\hline $\mathbf{T}_{\mathbf{2}}$ & $1 \times \mathrm{M}_{4}+1 \times \mathrm{M}_{2}+1 \times \mathrm{M}_{3}$ & 3155.91 \\
\hline
\end{tabular}

Table.5 Cost of operation of different treatment

\begin{tabular}{|c|c|c|}
\hline Treatments & Combination & Cost, ₹ /ha \\
\hline $\mathbf{T}_{\mathbf{1}}$ & $1 \times \mathrm{M}_{1}+1 \times \mathrm{M}_{2}+1 \times \mathrm{M}_{3}$ & 5308.22 \\
\hline $\mathbf{T}_{\mathbf{2}}$ & $1 \times \mathrm{M}_{4}+1 \times \mathrm{M}_{2}+1 \times \mathrm{M}_{3}$ & 5829.87 \\
\hline
\end{tabular}


Fig.1 Mulcher $\left(\mathrm{M}_{1}\right)$

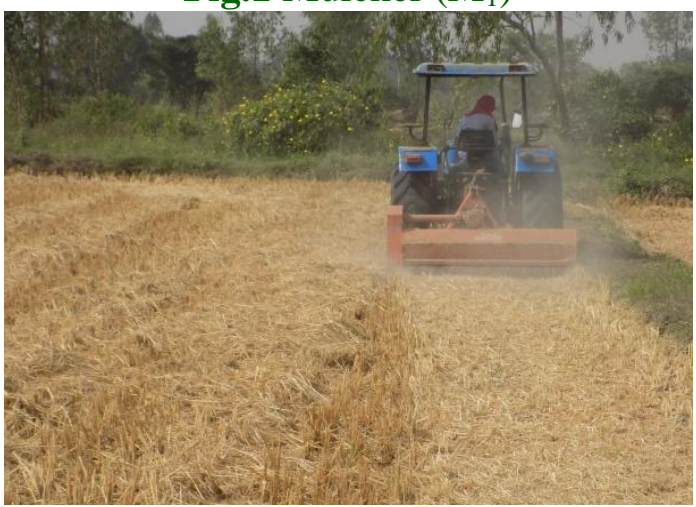

Fig.3 Rotavator $\left(\mathrm{M}_{3}\right)$

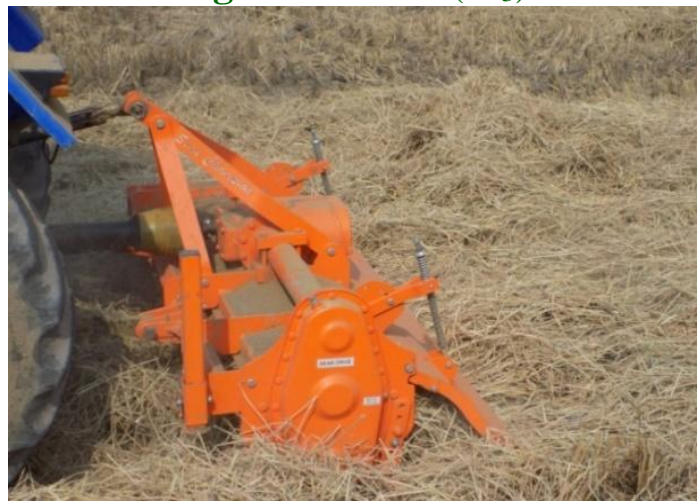

Fig.2 Disc plough $\left(\mathrm{M}_{2}\right)$

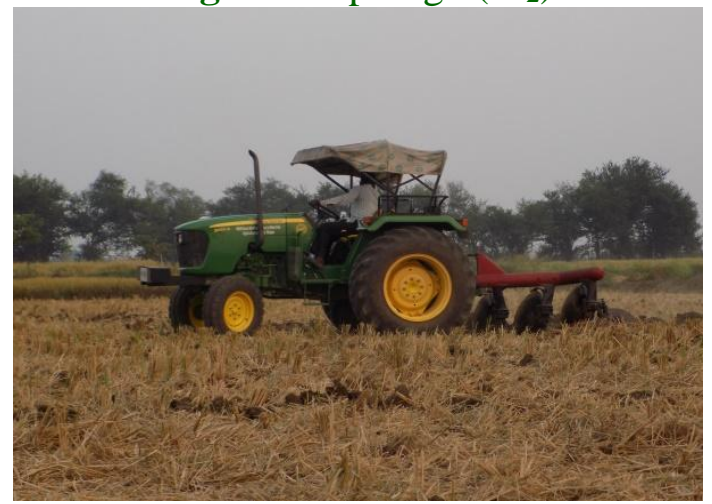

Fig.4 Straw chopper $\left(\mathrm{M}_{4}\right)$

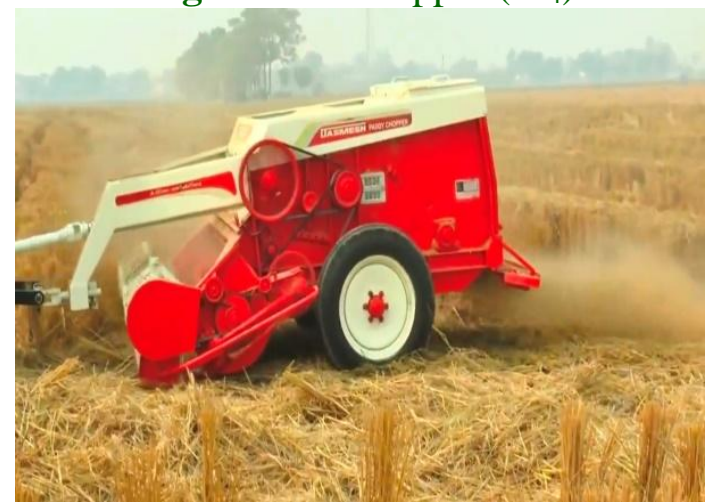

Fig.5 Energy requirement in per cent of different implements under different treatments

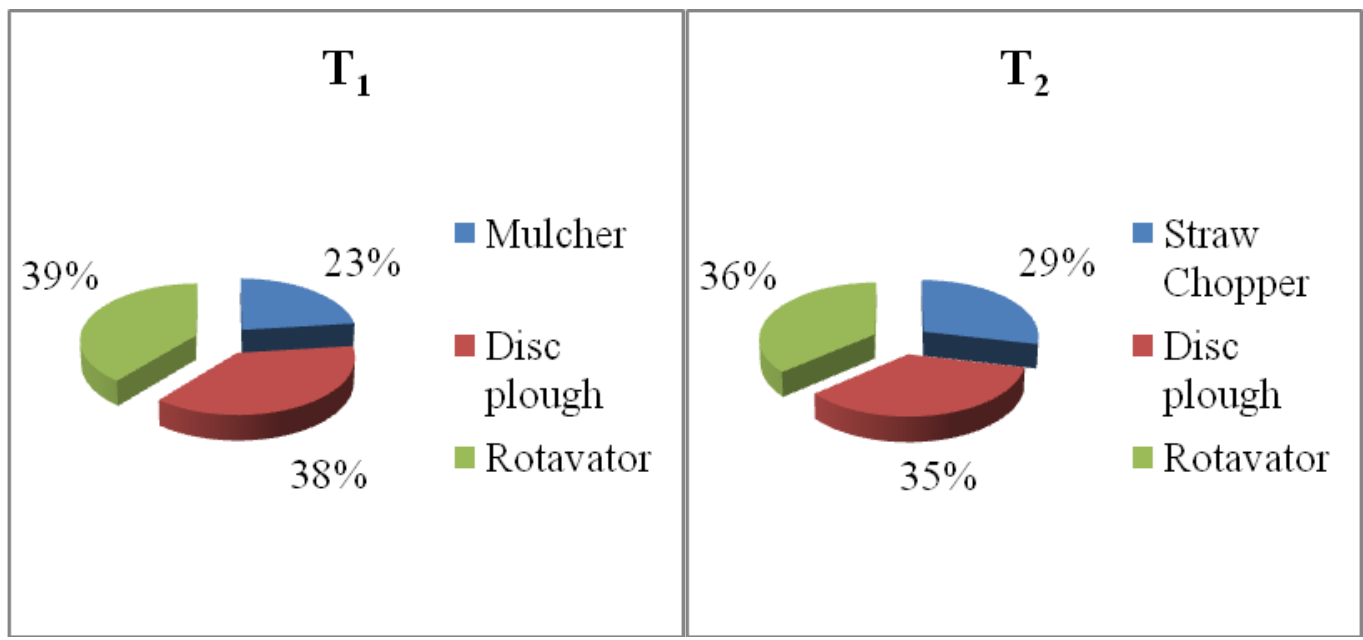


Fig.6 Cost of operation in per cent of different implements under different treatments

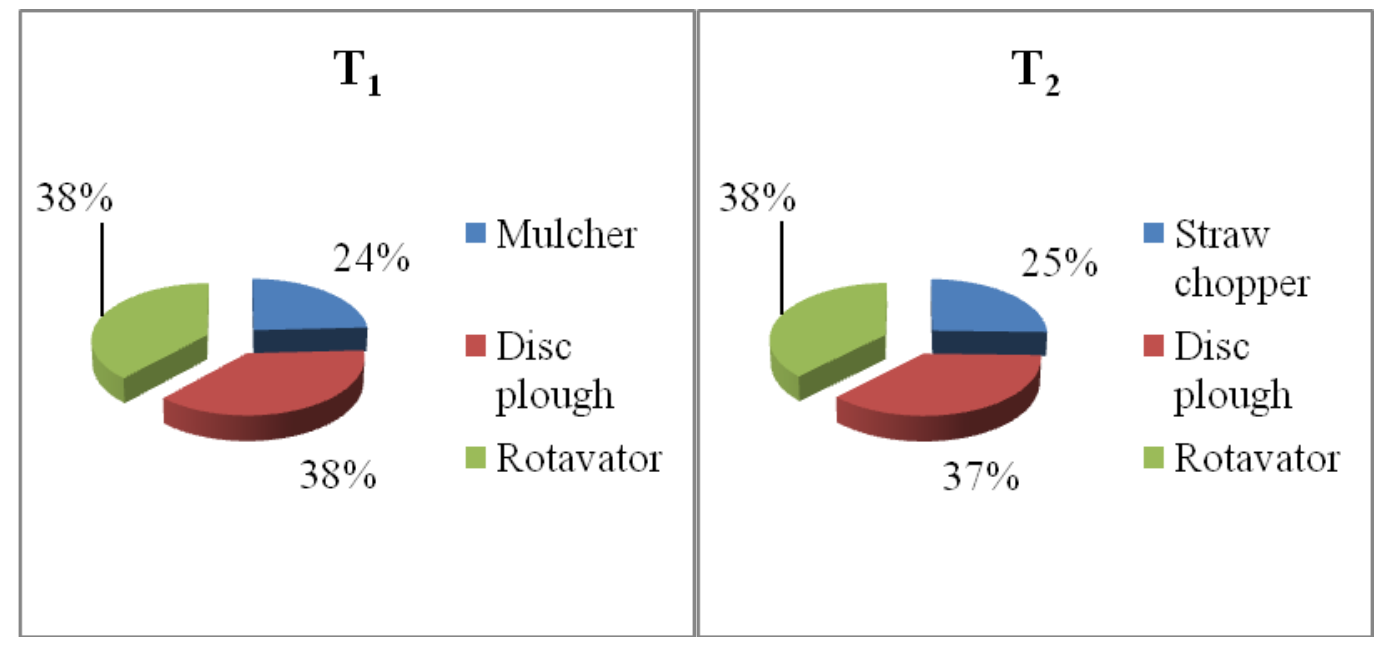

\section{References}

Anynomous, 2017. Season-wise Area, Production and Productivity of Rice in India. Indiastat.

Cook J, Huggins D and Schillinger W (2000).Straw management and crop rotation alternative to burning straw. Thesis, College of Agriculture and Home Economics.Washington State University, Pullman, WA 99163.

Kamboj P 2012. Study of farm machinery services provided by selected cooperative societies. Agricultural Engineering International: CIGR Journal, 14(4): 123-133.

Kenneth JE, Darrell EB and Andrew BB (2005). Managing crop residue with farm machinery, United States.
Kumar P, Kumar S and Joshi L (2015) Socioeconomic and Environmental Implications of Agricultural Residue Burning, Springer Briefs in Environmental Science. 141.

Midwood J and Bivbeck P (2012). Mangaing heavy stubble loads and crop residue.

SinghS and Mittal JP 1992. Energy in production agriculture. Mittal Publications.

Thakur SS and Garg IK 2007. Paddy straw management by chopping for sowing wheat in combine harvested field. Journal of Research, 44(3):243-248.

Verma A, Singh A, Singh A, Sidhu GS and Dixit A 2016. Performance evaluation of tractor operated paddy straw mulcher. Journal of Krishi Vigyan, 4(2):70-75.

\section{How to cite this article:}

Suryakant Sonwani, M. Quasim, Ajay Verma and Pushpraj Diwan. 2019. Incorporation of Residue into the Soil in Combine Harvested Paddy Field by Machineries Combination. Int.J.Curr.Microbiol.App.Sci. 8(11): 1384-1391. doi: https://doi.org/10.20546/ijcmas.2019.811.161 